\title{
Depression, Anxiety, and Stress in Stroke Patients in Lhokseumawe City, Indonesia
}

\author{
Erna Masdiana $^{1 *}$, Syarifah Rauzatul Jannah ${ }^{2}$, Kartini Hasballah ${ }^{2}$ \\ ${ }^{\mathrm{T}}$ Master Program of Nursing Science, Syiah Kuala Universitas University, Jl. Teuku Nyak Arief No.441, Kopelma Darussalam, Kec. \\ Syiah Kuala, Kota Banda Aceh, Aceh 23111, Indonesia \\ ${ }^{2}$ Master of Nursing Study Program, Faculty of Nursing, Syiah Kuala University, Jl. Teuku Nyak Arief No.441, Kopelma Darussalam, \\ Kec. Syiah Kuala, Kota Banda Aceh, Aceh 23111, Indonesia
}

\section{Article History \\ Received: 11.12.2021 \\ Accepted: 13.01.2022 \\ Published: 09.02.2022 \\ Journal homepage: \\ https://www.easpublisher.com}

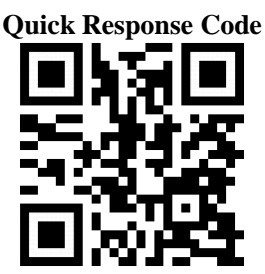

Abstract: Strokes or disorders of the neurovascular system continue to increase, leading to increased disability and death rates. This research aims to determine the level of depression, anxiety, and stress of stroke patients at the Lhokseumawe Hospital. A cross-sectional design with a total sample of 113 respondents was used. Furthermore, to measure the level of depression, anxiety, and stress, the Depression Anxiety Stress Scale (DASS-21) questionnaire consisting of 21 questions with a Likert scale of $0-3$ was used. The results showed that the majority of respondents experienced mild depression (34.5\%), moderate anxiety (55.8\%), and normal stress levels $(33.6 \%)$. Therefore, health services should investigate patients' mental health with chronic diseases such as stroke to avoid persistent complications.

Keywords: Depression, Anxiety, Stress, Stroke.

Copyright (C) 2022 The Author(s): This is an open-access article distributed under the terms of the Creative Commons Attribution 4.0 International License (CC BY-NC 4.0) which permits unrestricted use, distribution, and reproduction in any medium for non-commercial use provided the original author and source are credited.

\section{INTRODUCTION}

Stroke is a significant problem related to mortality and disability in the world. Patients typically suffer from hemiplegia or paralysis, speech and neurovascular system disorders that become health problems, which require appropriate treatment (Grotta, 2016). In addition, the effects of this disease cause psychosocial problems such as depression, anxiety, and stress that can impair a person's ability to interact socially with others (Hastuti, 2014). Psychosocial problems are very common in all stroke patients, ranging from being unprepared to accept weakness and helplessness, making them feel useless. These situations lead to anxiety and depression due to long-term complications, as well as decreased self-esteem due to social changes that often occur but are usually not realized by patients, families, or health workers, therefore, these psychosocial problems are not considered (Saam \& Wahyuni, 2012).

Previous research related to depression, anxiety, and stress in stroke patients reported that many did not accept their condition (Sumbogo, Sulisno, \&
Darwati, 2015). Another research mentioned that stroke patients show negative behavior (Zarmi. 2017), while others reported that three psychosocial factors appear in stroke patients such as depression, high expectations, and low self-esteem (Choi, 2015). The factors that cause psychosocial problems are biological, psychological, and socio-cultural (Stuart, 2016). Other research showed that stroke survivors will experience four changes such as physical, independent, psychosocial responses, and coping strategies (Loupatty, 2019). These conditions worsen the physical condition and psychologically, therefore, increased psychosocial pressure is at risk of death (Mahadevan, 2021).

\section{METHOD}

This Cross-sectional research was conducted from November 29 to December 13, 2021. The samples used were 113 stroke patients, while data were collected by filling out a questionnaire assisted by the room nurse. The questionnaire used is the Depression, Anxiety, and Stress Questionnaire using the Depression Anxiety Stress Scale (DASS-21), consisting of 21

*Corresponding Author: Erna Masdiana

Master Program of Nursing Science, Syiah Kuala Universitas University, Jl. Teuku Nyak Arief No.441, Kopelma Darussalam, Kec. Syiah Kuala, Kota Banda Aceh, Aceh 23111, Indonesia 
question items with a Likert scale of 0-3. This research was approved by the ethics committee. Respondents were taken after signing the informed consent.

\section{STATISTIC ANALYSIS}

Descriptive statistics are used to determine the level of depression, anxiety, and stress. Data analysis was carried out using SPSS version 20 software.

\section{RESULT}

a. Summary of respondents' depression, anxiety, and stress levels.

\section{Table 1: Summary of patient characteristics and condition $(n=113)$}

\begin{tabular}{|l|l|l|l|}
\hline No & Variable & Frequency (f) & Percentage (\%) \\
\hline 1 & Depression & & \\
& Normal & 26 & 23.0 \\
& Mild & 39 & 34.5 \\
& Moderate & 25 & 22.1 \\
& Severe & 23 & 20.4 \\
\hline 2 & Anxiety & & \\
& Normal & 11 & 9.7 \\
& Mild & 12 & 10.6 \\
& Moderate & 63 & 55.8 \\
& Severe & 27 & 23.9 \\
\hline 3 & Stress & & \\
& Normal & 38 & 33.6 \\
& Mild & 9 & 8.0 \\
& Moderate & 29 & 25.7 \\
& Severe & 37 & 32.7 \\
\hline
\end{tabular}

Out of the 113 respondents who received a questionnaire, the results showed that they experienced mild depression $(34.5 \%)$, moderate anxiety $(55.8 \%)$, and normal stress levels (33.6\%).

\section{DISCUSSION}

This research describes the level of depression, anxiety, and stress experienced by stroke patients at Lhokseumawe Hospital. The results showed they had mild depression (34.5\%), moderate anxiety (55.8\%), and normal stress $(33.6 \%)$.

Psychosocial problems are psychological or social changes in a person's life, which have an influence and are considered a significant potential factor for causing mental or health disorders that cause real mental illness or otherwise mental health problems that affect the social environment (Oktowaty, 2018). Risk factors for psychosocial problems in individuals with chronic diseases include emotional intelligence, self-concept, motivation, coping mechanisms, social support, and helplessness (Mayer, JD (2016), Sobur (2003), Robin (2001), Nasir and Muhith (2011), Solomon (2004), Nanda (2011)). Stroke attacks the nervous system and the human musculoskeletal system, therefore, this disease creates complex problems for those affected. The nerve disorders that occur cause problems such as speech impairment, thought processes, and other disabilities, while the musculoskeletal system causes more objective problems such as the inability to move and the patient's inability to fulfill the daily needs. This causes psychosocial problems such as depression, anxiety, and stress (Jameson et al., 2018).

The research of (Almhdawi et al., 2021) showed that the proportion of stroke patients with symptoms of mental disorders was $74.5 \%$, depression, $52.9 \%$, anxiety, and stress $68 \%$. There are significant results in stroke patients experiencing depression, anxiety, and stress due to changes in roles that occur in their bodies. When they are healthy, they can do activities on their own, but when they are sick, they need help. This leads to depression about their weakness and anxiety in thinking about family life. The research by (Zhao et al., 2021) showed that social support is closely related to the occurrence of symptoms of anxiety and depression in stroke patients. They need more help from their loved ones to fulfill their daily needs, such as bathing, eating, and other physiological needs. This will certainly have an impact on stroke patients who do not get full social support from their environment and cause symptoms of more severe mental disorders. The research by (van Rijsbergen, Mark, Kop, de Kort, and Sitskoorn, 2019) stated that there is a significant relationship between anxiety and depression in post-stroke patients.

\section{CONCLUSION}

Based on the results, it can be concluded that stroke patients experienced mild depression (34.5\%), moderate anxiety $(55.8 \%)$, and normal stress levels $(33.6 \%)$. It is expected that health services will be able to identify symptoms of mental disorders in stroke patients from the beginning.

\section{REFERENCES}

- Almhdawi, K. A., Alazrai, A., Kanaan, S., Shyyab, A. A., Oteir, A. O., Mansour, Z. M., \& Jaber, H. (2021). Post-stroke depression, anxiety, and stress symptoms and their associated factors: A crosssectional study. Neuropsychological Rehabilitation, 31(7),

1091-1104. https://doi.org/10.1080/09602011.2020.1760893

- Jameson, J. L., Kasper, D. L., Longo, D. L., S.Fauci, A., L.Hauser, S., \& Loscalzo, J. (2018). https://t.me/MBS_MedicalBooksStore.

- Jung, M. Y., Yoo, E. Y., Lee, J. S., Park, Soo HyuChoi, Y. I., \& Park, J. H. (2015). Psychosocial predictors of participation restriction poststroke in Korea: A path analysis. Rehabilitation Psychology, 60(3),

286-294. https://doi.org/10.1037/rep0000051

- Oktowaty, S., Setiawati, E. P., \& Arisanti, N. (2018). Hubungan Fungsi Keluarga Dengan Kualitas Hidup Pasien Penyakit Kronis Degeneratif di Fasilitas Kesehatan Tingkat Pertama. Jurnal 
Sistem Kesehatan, 4(1), 1-6. https://doi.org/10.24198/jsk.v4i1.19180

- Suaryana, I. K., Aryani, L. N. A., \& Lesmana, C. B. J. (2020). The correlation of caregiving burden with depression, anxiety, and stress among caregivers of people with schizophrenia. Journal of Clinical and Cultural Psychiatry, 1(2), 21-24. https://doi.org/10.36444/jccp.v1i2.11

- Sumbogo, A., Sulisno, M., \& Darwati, L. E. (2015). Gambaran respons psikologis penderita stroke. Jurnal Ilmiah Permas, 5(1), 29-37.

- van Rijsbergen, M. W. A., Mark, R. E., Kop, W. J., de Kort, P. L. M., \& Sitskoorn, M. M. (2019). Psychological factors and subjective cognitive complaints after stroke: Beyond depression and anxiety. Neuropsychological Rehabilitation, 29(10), 1671-1684. https://doi.org/10.1080/09602011.2018.1441720

- Zhao, Y., Hu, B., Liu, Q., Wang, Y., Zhao, Y., \& Zhu, X. (2021). Social support and sleep quality in patients with stroke: The mediating roles of depression and anxiety symptoms. International Journal of Nursing Practice, (November 2020), 111. https://doi.org/10.1111/ijn.12939

- Grotta, J. C., Albers, G. W., Broderick, J. P., Kasner, S. E., Lo, E. H., Mendelow, A. D., Sacco, R. L., \& Wong, L. K. S. (2016). Stroke
Pathophysiology, Diagnosis, and Management (6th ed.). Elsevier.

- Hastuti, I. D., Setiawan, R., \& dan Fikri, J. (2014). Hubungan Dukungan Sosial dengan Kualitas Hidup pada Penderita Tuberkulosis Paru di Balai Kesehatan Kerja Masyarakat Propvinsi Jawa Barat Tahun. Bhakti Kencana Medika, 4(1), 1-74

- Zarmi. (2017). Hubungan Kondisi Fisik Dan Mekanisme Koping Individu Dengan Harga Diri Penderita Pasca Stroke Di Poliklinik Saraf Rsud Raden Mataher Jambi, 6(2), 12-21. Jurnal Akademika Baiturrahim Martha Suri, Daryanto Vol.6 No.2 : diakses tanggal 04 September 2021

- Choi, Y. I., Park, J. H., Jung, M. Y., Yoo, E. Y., Lee, J. S., \& Park, S. H. (2015). Psychosocial predictors of participation restriction poststroke in Korea: A path analysis. Rehabilitation Psychology, 60(3), 286.

- $\quad$ Loupatty, S. N., Ranimpi, Y. Y., \& Rayanti, R. E. (2019). Respon Psikososial dan Strategi Koping Pasien Stroke dalam Konteks Budaya Ambon. Jurnal Kesehatan, $\quad$ 10(3), 480. https://doi.org/10.26630/jk.v10i3.1121

- $\quad$ Stuart, G. W. (2016). Buku Saku Keperawatan Jiwa (pocket guide to psychiatric nursing). Edisi V. Jakarta: EGC.

Cite This Article: Erna Masdiana, Syarifah Rauzatul Jannah, Kartini Hasballah (2022). Depression, Anxiety, and Stress in Stroke Patients in Lhokseumawe City, Indonesia. EAS J Nurs Midwifery, 4(1), 21-23. 